\title{
The Effect of Prior Knowledge of English at Elementary School on the Reading Ability of Junior High School Students
}

\author{
Roudhotul Hildayani \\ STKIP PGRI Sidoarjo, Email: roudhotulhildayani@gmail.com
}

\begin{abstract}
This research is used quantitative method and the design used in this research was ex post facto. In collecting the data, the reseacher administer questionairre then share the reading test to the students. In analyzing the data, the reseacher used linear regression in SPSS 16.0.the result of this research shows that there is effect or influence between prior knowledge of english and reading ability. Based on the calculation linear reggresion, the gain of sig is 0.021 which is less than 0.05 . it mean $\mathrm{s}$ that prior knowledge of english at elementary school influence the reading ability of junior high school students. It can be concluded that the students who get prior knowledge of english at elementary school are having better reading ability than those who do not.
\end{abstract}

Keywords : Prior knowledge, Prior knowledge of english, Reading ability.

\section{INTRODUCTION}

Reading for EFL students is very important, especially those who are at Junior High School. By reading, they can elaborate the content of the text into other English Language skills, such as listening, writing, and speaking. The progress of researcher for each student is different due to the fact that they have prior knowledge of reading before studying at Junior High School.

Every student has different prior knowledge. Because they each have their own prior knowledge. The prior knowledge is information that children have developed through their experiences in their cultures and families (Moll, Amanti, Neff, and Gonzales, 1992). For the example, English is taught at Kindergarten and Elementary school, some students have had course, some students may have lived in another country, and they may have traveled little.

Based on the description above, this study focuses on the prior knowledge at Elementary School due to finding the result whether there is an effect of English got an Elementary School on the reading ability of Junior High School students. 


\section{METHOD}

This research design is an ex post facto. It is Non experimental designs that are used to investigate causal relationships without the treatments. Hence, it examines the possible changes of an effect, phenomena, and behavior caused by one event. As consequences, this study is aimed at finding out whether prior knowledge of English influences the reading ability.

In this research, source of data are the students, the score's of the students, and the supporting score of the students. The source of data is the person and the process which is observed (arikunto, 2002: 107). The researcher use observation to get the data. The data in this research is result of Questionnaire and reading test. The test is about reading which includes students' understanding of reading. The technique used in collecting the data on the influence of prior knowledge of English on reading ability is a questionnaire and reading test.

This research used software of SPSS 16.0 to analyze the data. After getting the data from questionnaire and documentation, furthermore it is important to analyze the data to examine the hypothesis. This research used linear regression to investigate between the influence of questioning strategy and students' achievement in reading. Hence, linear regression is regression analysis which is used to learn the functional relationship between the variables (Susetyo, 2010:125). Therefore, linear regression is appropriate to be used to test the causal relationship between two variables. Basically, linear regression is different with linear correlation; linear correlation is used to test between the relationship of two variables and the degree of variable $\mathrm{X}$ and $\mathrm{Y}$ can be changed their position or it can be said it is a vice versa relationship. While the linear regression, the degree of the variables $\mathrm{X}$ and $\mathrm{Y}$ cannot be changed or it can be said it is a causal relationship (Ibid). Furthermore, this study used F-test to test the hypothesis. F-test is used to examine the influence of independent variable and dependent variable.

After obtaining the questionnaire and documentation, then the writer will analyze data of questionnaire score and students' reading achievement score into some steps, they are analyze the score of students' reading test and then input them in the SPSS 16.0. Input the score of students' reading achievement into SPSS 16.0. Examine linear reggression to test the hypothesis at SPSS 16. 


\section{FINDINGS AND DISCUSSION}

\section{Findings}

The researcher will discuss the research findings about prior knowledge of English at elementary school on reading ability. The first step, the researcher will discuss the description of students' questionnaires scores which is regarded as prior knowledge of English. Furthermore, the researcher will report the result of linear regression which examines the hypothesis of the study.

\section{Data Description}

The research data consists of prior knowledge of English as an independent variable and reading ability as a dependent variable. The data had been collected through questionnaire to know the students' prior knowledge of English and documentation about students' reading score which was obtained based on the reading test. The data description shows the minimum and maximum score of prior knowledge of English and reading test score. All of those data description will be discussed in the following discussion comprehensively.

\section{Students' prior knowledge}

To know the students' prior knowledge of English, the researcher distributed questionnaire to students of MTs Darul Huda as the object of the research. After collecting the data of students' prior knowledge of English, the researcher identified the questionnaire which one got the English and which one did not get English.

\section{Students' Reading Achievement}

Students' reading achievement is the final score of reading ability which is obtained based on the reading test score and reading comprehension score in the seventh grade of MTs Darul Huda. After collecting the data, the researcher calculated the score. The score of reading test can be seen in the table as follows: 
The Effect of Prior Knowledge of English at Elementary School on the Reading Ability of Junior High School Students

Table. 1 Students Reading Achievement

\begin{tabular}{|c|c|}
\hline Student & Reading Test \\
\hline 1 & 80 \\
\hline 2 & 80 \\
\hline 3 & 80 \\
\hline 4 & 80 \\
\hline 5 & 75 \\
\hline 6 & 75 \\
\hline 7 & 50 \\
\hline 8 & 65 \\
\hline 9 & 60 \\
\hline 10 & 75 \\
\hline 11 & 80 \\
\hline 12 & 65 \\
\hline 13 & 65 \\
\hline 14 & 65 \\
\hline 15 & 78 \\
\hline 16 & 80 \\
\hline 17 & 80 \\
\hline 18 & 80 \\
\hline 19 & 75 \\
\hline 20 & 75 \\
\hline 21 & 80 \\
\hline 22 & 80 \\
\hline
\end{tabular}

The table1. which represent students' answer shows that the highest score of the reading test is 80 and the lowest score is 50 . It can be concluded that there is significant difference between the highest and the lowest score of the students' answering with the range 30 . Then the sum score of students' answering is 1623. All of the data descriptions above were calculated by using descriptive statistic SPSS 16.0.

\section{Discussion}




\section{The Testing of Hypothesis}

The testing of hypothesis is aimed to examine between two variables which is prior knowledge of English as an independent variable and reading ability as a dependent variable. Hence, the researcher analyzed the data between two variables by using linear regression in SPSS 16.0 to see whether the prior knowledge influences students' reading ability. Furthermore, based on the calculation of SPSS 16.00, the data gathered as follow:

Table. 2 Result of ANOVA

\begin{tabular}{|c|c|c|c|c|c|c|}
\hline \multicolumn{2}{|c|}{ Model } & $\begin{array}{l}\text { Sum of } \\
\text { Squares }\end{array}$ & $\mathrm{df}$ & Mean Square & $\mathrm{F}$ & Sig. \\
\hline \multirow[t]{3}{*}{1} & Regression & 399.032 & 1 & 399.032 & 6.325 & $.021^{\mathrm{a}}$ \\
\hline & Residual & 1261.741 & 20 & 63.087 & & \\
\hline & Total & 1660.773 & 21 & & & \\
\hline
\end{tabular}

a. Predictors: (Constant), Reading_ability

b. Dependent Variable: Prior_knowledge

Hypothesis:

$\mathrm{Ha}$ : there is an influence of prior knowledge of English on reading ability.

Ho : there is no influence of prior knowledge of English on reading ability.

Criteria of the test:

$\mathrm{H}_{\mathrm{o}}$ is accepted if probability ( $\left.\mathrm{sig}\right)>0.05, \mathrm{H}_{\mathrm{a}}$ is accepted probability (sig.) $<0.05$

Based on the table above, the gain of sig is 0.021 which is less than $0.05(0.021<0.05)$. It can be concluded that $\mathrm{H}_{\mathrm{a}}$ is accepted and $\mathrm{H}_{\mathrm{o}}$ is rejected. It means that prior knowledge of English at elementary school influence the reading ability.

\section{Data Interpretation}

Prior knowledge of English is a knowledge which concern in new knowledge which is beneficial for students to help them facing reading difficulty. In addition, it is also profitable for students to be an effective reader because the student has prior knowledge of English. 
Therefore, it is important to investigate the correlation between prior knowledge of English with reading ability.

There is same characteristic between two variables which is prior knowledge of English and reading ability. In addition, according to the criteria of hypothesis above, it indicates the results of probably ( $\mathrm{sig}$ ) or $0.021<0.05$. it can be concluded that prior knowledge of English influence reading ability of the students.

\section{CONCLUSION}

Based on the table above, the gain of sig is 0.021 which is less than $0.05(0.021<0.05)$. It can be concluded that $\mathrm{H}_{\mathrm{a}}$ is accepted and $\mathrm{H}_{\mathrm{o}}$ is rejected. It means that prior knowledge of English at elementary school influence the reading ability. In addition, there is influence or there is an effect between prior knowledge of English and reading ability of the students. It can be concluded that the research of the effect of prior knowledge of English at elementary school on reading ability of junior high school students has a significant influence or effect for the seventh grade of MTs Darul Huda. Therefore, prior knowledge of English is beneficial for students to gain their achievement reading.

\section{REFFERENCES}

Alderson, J. Charles. 2000. Assessing Reading. Cambridge: Cambridge University press.

Alexander, Christoper. 1977. A Pattern Language: Towns, Buildings, Construction. New York: Oxford University Press.

Arikunto, Suharsimi. 2008. Metodologi PenelitIAN. Penerbit: PT Rineka Copta, Jakarta.

Brown, H. Douglas. 2001. Teaching by principles an Interactive approach to Language pedagogy ( $2^{\text {nd }}$ Ed.). New York: Addison Weslew Longman. Inc.

Brown, H.G. 2004. Languagr assessment: Principles and Classroom Practices. New York: Longman.

Budi, Susetyo, Statistika Untuk Analisis Data Penelitian (PT Refika Aditama Bandung,2010), p. 125.

Caldwell, JoAnne Schudt. Reading Assessment: A primer for Teachers and Coaches Second Edition. New York: The Guilford Presss. 2008.

Catherine, Snow. 2002. Reading for Understanding: toward a research and development program in. Pittsburgh, Pennsylvania, Pittsburgh.

Creswell, J.W. 1994. Research Design: Qualitative and Quantitative Approaches Thousand 
Oaks, CA: Sage.

Davis, Keith. 1972. Human Behavior at Work: Human relations anfd organizational Behavior, Fourth Edition. McGraw-Hill, New York.

De Vos, A. S., Schurink, E.M. \& Strydum, H. 1998. The nature of research in The Caring Professions. In De Vos, A. (Ed.) Research at The Grass Roots; A Primer for The Caring Professions. Pretoria, J.L. Van Schalk.

Dubin, Fraida, B. 1986. Teaching Second language Reading for Academia purposes. USA: Addison Wesley Publishing Company.

Eskey, D. E, and W. Grabe. 1988. Interactive Models for Second Language reading: Perspectives on Instruction. In Carrell, devine and eskey 1988. 223-38.

Grellet, Francoise. 1982. Developing Reading Skills: A Guide to Reading Comprehension Exercises. Cambridge: Cambridge University Press.

Harmer, J. 2002. The Practice of English Language Teaching. Harlow, Essex: Longman. 2003. How to Teach English: an Introduction to the Practice of English Language Teaching. Harlow, Essex: Longman.

Harmer, J. 2007. How to Teach English. London: Longman.

Heilman, Blair and Rupley. 1981. Principle and Practice of Teaching Reading. $5^{\text {th }}$ Edition Colombus Ohio: Charles e. Merrill Publishing Co.

Kvale, S.I. 1996. Interview Views: An Introducing to Qualitative Research Interviewing. Thousand Oaks. CA: Sage Publications.

Masri Singarimbun and Sofian Effendi, Metode Penelitian Survai, (penerbit LP3ES Indonesia , 2006), p. 124.

Moll, L. C., Amanti, C., Neff, D., \& Gonzalez, N. (1992). Funds of Knowledge for Teaching: Using a Qualitative Approach to Connect Homes and Classrooms. Theory into Practice, 31. 132-141.

Nunan, david. 1989. Designing Tasks for the Communicative Classroom. University of Cambridge: Cambridge University Press.

Oppenheim, A.N. 2001. Questionaire Design, Interviewing, and attitude Measurement. New Edition. Continuum. London and New York.

Rivers, Wilga, M. 1981. Teaching Foreign-Language Skill (second edition). Chicago and London: The university of Chicago Press.

Smith, F. 1982. Reading Without Nonsense. New York: Teachers College Press.

Sofian Siregar, Statistika Deskriptif untuk Penelitian. (Jakarta: Rajawali Press, 2011). 
The Effect of Prior Knowledge of English at Elementary School on the Reading Ability of Junior High School Students

Sugiyono, Metode Penelitian , Pendidikan,Pendekatan Kuantitatif, Kualitatif, dan R\&D, (Alfabeta Bandung, 2013), p. 85.

Vaughn, S. \& Bos,S.C. 2009. Strategies for Teaching Students with Learning and Behaviour Problems (seven edition). USA: Pearson. 